\title{
Experimental investigation of multi-span post-tensioned glass beams
}

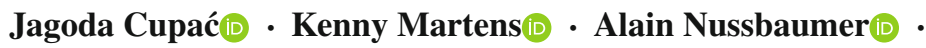 \\ Jan Belis $(1)$ - Christian Louter $(\mathbb{B}$
}

Received: 2 September 2016 / Accepted: 28 January 2017 / Published online: 8 March 2017

(C) The Author(s) 2017. This article is published with open access at Springerlink.com

\begin{abstract}
This paper presents a study on posttensioned glass beams in a statically indeterminate system. In order to increase the safety of structural glass beams, ductile reinforcement can be added to glass beam sections providing secondary load carrying mechanism in case of glass breakage. In the here investigated post-tensioned system, the reinforcement tendons are additionally pre-tensioned, introducing compressive pre-stress in the beam in order to increase
\end{abstract}

\section{J. Cupać}

Resilient Steel Structures Laboratory (RESSLab), School of Architecture, Civil and Environmental Engineering (ENAC), École Polytechnique Fédérale de Lausanne (EPFL), GC B3 465, Station 18, 1015 Lausanne,

Switzerland

e-mail: Jagoda.Cupac@epfl.ch

K. Martens · J. Belis

Laboratory for Research on Structural Models (LMO), Department of Structural Engineering, Faculty of Engineering and Architecture, Ghent University, Technologiepark-Zwijnaarde 904, 9052 Ghent, Belgium e-mail: Kenny.Martens@ugent.be

\footnotetext{
A. Nussbaumer

Resilient Steel Structures Laboratory (RESSLab), School of Architecture, Civil and Environmental Engineering (ENAC), École Polytechnique Fédérale de Lausanne (EPFL), GC B3 495, Station 18, 1015 Lausanne,

Switzerland

e-mail: Alain.Nussbaumer@epfl.ch

J. Belis

Structural Design Unit, Department of the Built

Environment, Eindhoven University of Technology (TU/e),

Eindhoven, The Netherlands

e-mail: Jan.Belis@ugent.be
}

the apparent tensile strength of glass. The system is tested in five-point bending at 23 and $60^{\circ} \mathrm{C}$ in order to investigate the basic structural performance and the influence of temperature increase on the initial cracking load and the behaviour of the cracked beam. The benefit of the here investigated statically indeterminate system is a more economical design, i.e. lowering of the bending moment in the span of an equivalent simply supported system by continuing the beam over the central support. The efficiency of the applied system is compared to a reinforced beam system produced in the same batch with similar overall dimensions. The results show an increase of initial cracking load of the post-tensioned beams due to the applied pre-stress and a ductile post-cracking response, reaching high ultimate loads prior to failure. At $60^{\circ} \mathrm{C}$ both reinforced and post-tensioned beams show lower initial cracking loads and limited post-cracking ductility but still significant load reserve with ultimate loads well above the initial cracking loads, providing safe failure behaviour.

Keywords Structural glass beam · Post-tensioned . Statically indeterminate - Multi-span · Ductility . Experiment

\footnotetext{
C. Louter $(\varangle)$

Chair of Structural Design, Department of Architectural Engineering and Technology $(\mathrm{AE}+\mathrm{T})$, Faculty of Architecture and the Built Environment (A+BE), Delft University of Technology (TU Delft), Julianalaan 134, 2628BL Delft, The Netherlands e-mail: Christian.Louter@TUDelft.nl
} 


\section{Introduction}

The brittle nature of glass calls for adequate safety concepts when glass is applied in a structural manner. Due to the presence of flaws on the glass surface resulting from production and handling of glass elements, glass is particularly sensitive to crack-opening tensile stresses. For structural glass beams, specific safety concepts have been developed over the past years that make use of the composite action between glass and an additive tendon placed at the tensile region of a glass beam. Upon initial glass cracking induced by bending, the tendon is able to bridge the cracks by taking over the tensile force. Along with a compressive force in the intact glass region an internal moment capacity is generated which allows the cracked beam to still carry significant load.

This safety concept has initially been developed in line with the principles of reinforced concrete, thereby creating so-called reinforced glass beams. A variety of research projects have focused on this topic; different materials such as steel, stainless steel, carbon fibre reinforced polymer (CFRP), glass fibre reinforced polymer (GFRP) and timber have been applied as reinforcement. The reinforcement is often adhesively bonded to the glass using alternative adhesives with a wide range of shear moduli. The obtained structural behaviour in general shows enhanced performance and ductility in the post-cracking phase, the extent of which depends on the properties of the reinforcing material and efficiency of the adhesive bond in transferring tensile forces from the cracked glass into the reinforcement. The result is a safe failure mechanism with high level of redundancy when compared to ordinary glass beams (Belis et al. 2009). A comprehensive overview of reinforced glass beams is provided in Martens et al. (2015).

Subsequently, the concept of reinforced glass beams has been taken a step further by applying a tensile pre-stress to the reinforcement tendon, in analogy to pre-stressed concrete. Rather than a passive tendon, now an active tendon induces compression in the glass and thus increases the cracking resistance of the glass beam subjected to tensile stresses in bending. In the post-cracking phase, the tendon remains an element for crack bridging, as in the reinforced beam system, providing safe failure behaviour.

Several research projects have explored the effects of post-tensioning glass beams. The concept was also applied in a building project, a glass roof of the spa Badenweiler, Germany (Schober et al. 2004). An overview of research and building projects is given in Martens et al. (2015). The observed behaviour has confirmed that the applied compressive pre-stress effectively postpones initial cracking of glass beams in bending, while in the post-cracking phase the tendon enables a secondary load-carrying mechanism by taking over the tensile stresses from the glass.

Basically, two post-tensioning strategies have been explored in earlier studies, which either make use of mechanically anchored or adhesively bonded tendons. The former-mechanically anchored-system relies on tendons, integrated in the glass web, or positioned alongside, that are mechanically anchored at the glass beam ends (Bos et al. 2004; Engelmann and Weller 2016; Jordão et al. 2014; Louter et al. 2014). Depending on the layout of the tendons and the beam geometry, axial compression or additionally a bending moment can be induced in the glass by applying tendons with a certain offset from the beam centroid. The second-adhesively bonded-system makes use of tendons pre-tensioned by an external mechanism and subsequently bonded along the edge of the glass beam (Cupać and Louter 2015; Louter et al. 2014). After curing of the adhesive, the tendon is released transferring pre-stress into the glass beam. By applying the tendon on either one or both beam edges, the glass beam is subjected to a bending moment and/or axial compression.

In the current study a combination of the abovementioned systems is applied. That is, a hybrid system in which the tendons are both adhesively bonded and mechanically anchored is investigated, as described in Sect. 3.1. This hybrid system provides several advantages. The adhesive bond generates composite action between the tendon and the glass beam, which increases the moment of inertia, i.e. the moment resistance, compared to a system in which the tendons are only mechanically anchored. Moreover, the hybrid system enhances the lateral stability of the pre-stressed beam by adhesively connecting the compressed glass element, which is prone to buckling, with the tensile steel elements along the full beam length. In this way, the allowable compressive preload is not limited by the critical buckling load of an unrestrained glass beam. In the post-cracking phase, the bond is expected to contribute to safe failure behaviour of the beam by providing overall integrity. Compared to a system with unanchored adhesively 


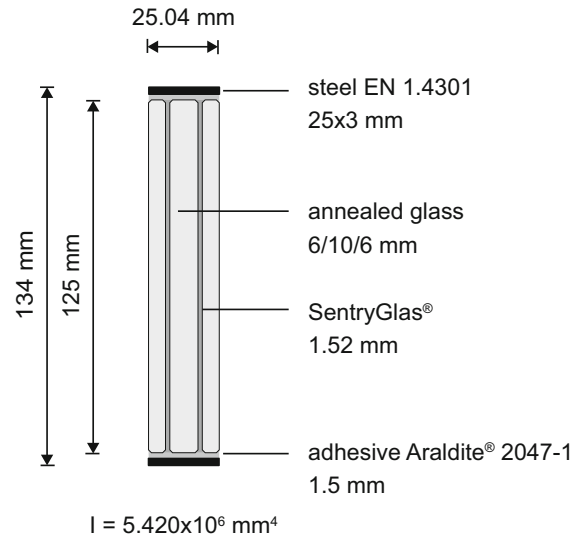

(a)

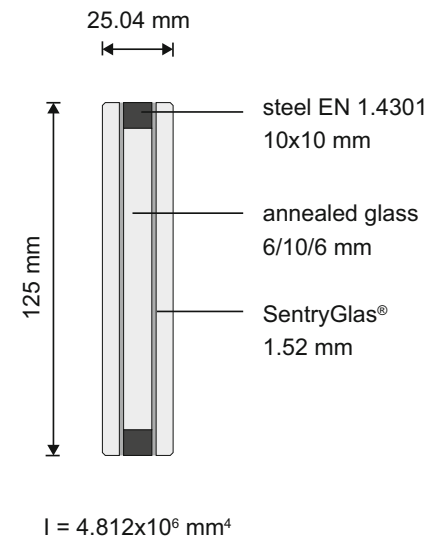

(b)

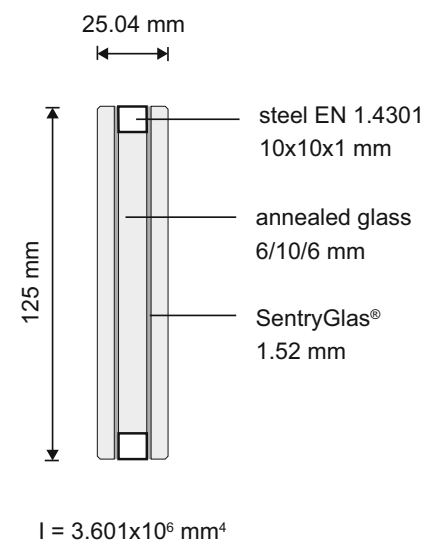

(c)

Fig. 1 Schematic cross-section with nominal dimensions of the post-tensioned (a) and reinforced (b, c) (Martens et al. 2016) glass beam specimens

bonded tendons, the effect of potential loss of prestress due to creep of the adhesive over time and/or at increased temperature is limited by mechanical anchoring.

The hybrid system is here explored through fivepoint bending experiments on $3 \mathrm{~m}$ long double-span post-tensioned glass beams, described in Sect. 3.2. The benefit of this statically indeterminate system is a more economical design, i.e. lowering of the bending moment in the span of an equivalent simply supported system by continuing the beam over the central support. Statically indeterminate systems have recently been explored for composite and reinforced glass beams (Martens et al. 2016; Valarinho et al. 2013), but have not yet been tested for post-tensioned glass beams. The current contribution therefore provides the experimental findings on multi-span post-tensioned glass beams, see Sect. 4, and compares them to earlier findings on reinforced glass beams presented in Martens et al. (2016). The latter reference is chosen for particular comparison because these beams were retrieved from the same manufacturer with consistent specifications and overall dimensions, and were tested on the very same bending setup. Furthermore, the current tests were performed at 23 and $60^{\circ} \mathrm{C}$ in order to investigate the temperature effect on the overall structural response, as was also done for the statically indeterminate reinforced glass beam system investigated in Martens et al. (2016).

\section{Specimens and materials}

The nominal cross-sectional dimensions of the $3 \mathrm{~m}$ long post-tensioned glass beam specimens investigated in the current study are given in Fig. 1a. The specimens consist of laminated glass, stainless steel tendons and methacrylate adhesive, as specified in the following subsections. In addition, the cross-sections of the reinforced glass beams (Fig. 1b, c) studied in Martens et al. (2016) are shown for comparison. Moments of inertia given in Fig. 1 are calculated taking into account full composite action between the glass and the steel and adopting $70 \mathrm{GPa}$ (EN 572-1 2004) and $200 \mathrm{GPa}$ (EN 1993-1-4 2006) for the E-modulus of glass and stainless steel, respectively.

\subsection{Laminated glass}

The glass beams for the current study were composed of three layers of annealed float glass of nominal thickness of $6 / 10 / 6 \mathrm{~mm}$ laminated by means of $1.52 \mathrm{~mm}$ thick SentryGlas ${ }^{\circledR}$ interlayers (Stelzer 2010). The perimeter of the glass beams was ground and polished after lamination. This guaranteed a perfect alignment of the glass layers and thus provided an even surface for the introduction of pre-stress through mechanical anchors at the beam ends, and an even bonding surface along the longitudinal edges, see Sect. 3.1. The laminated glass 


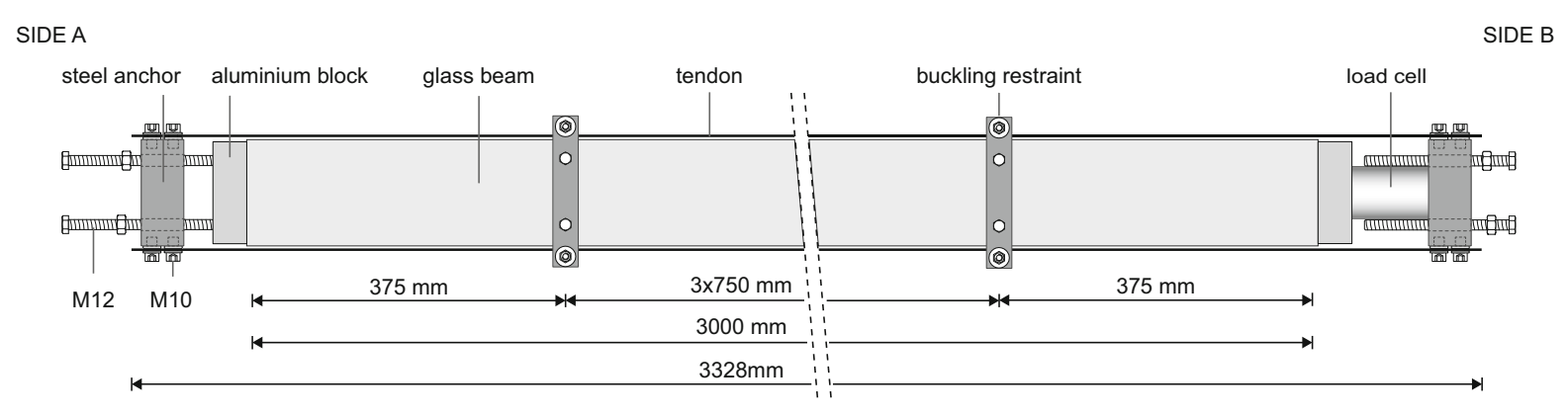

Fig. 2 Schematic layout of the post-tensioning setup

beams were provided by a professional glass processor and were produced in the same batch as the beams studied in Martens et al. (2016). The glass beams were received at the laboratory without post-tensioning system and were post-tensioned afterwards following the procedure described in Sect. 3.1.

\subsection{Post-tensioning tendons}

Flat stainless steel bars $25 \times 3 \mathrm{~mm}$, grade EN1.4301/ AISI304, with a length of $3328 \mathrm{~mm}$ were applied along the top and bottom edge of the glass beam and served as post-tensioning tendons. Apart from cleaning by means of isopropanol, no special surface treatment was applied to the stainless steel bars.

\subsection{Adhesive}

Stainless steel tendons were bonded to the glass by means of a gap-filling two-component methacrylate adhesive, Araldite ${ }^{\circledR}$ 2047-1 (Huntsman 2013 ${ }^{\circledR}$ ). This adhesive was selected based on earlier findings in associated research (Cupać and Louter 2015) and other research programs (Nhamoinesu and Overend 2012). The adhesive cures through the chemical reaction between the resin and the hardener component. The specimens in the current study were cured for $>48 \mathrm{~h}$ at $23^{\circ} \mathrm{C}$, in excess of the curing times recommended by the manufacturer. The glass transition temperature of the adhesive is $80^{\circ} \mathrm{C}$, given in the product datasheet, which is sufficiently high to maintain satisfactory performance at elevated temperatures expected to occur in glass structures, including the test temperature of $60^{\circ} \mathrm{C}$ explored in this study.

\section{Method}

\subsection{Post-tensioning setup}

The glass beams were manually post-tensioned using the setup schematically represented in Fig. 2. In total, six beam specimens were post-tensioned with a force of $30 \mathrm{kN}$. The following steps were taken:

1. Glass beams were laid flat on a table with steel tendons positioned along the longitudinal beam edges. Between the steel and the glass $1.5 \mathrm{~mm}$ thick Teflon spacers were applied at an interval of $750 \mathrm{~mm}$.

2. Custom-made brackets were placed around the assembly to restrict any relative lateral displacement between the glass and the tendons and thus to prevent buckling of the glass beam due to posttensioning. These buckling restraints consisted of two aluminium blocks with tightly fitting gaps for the tendons, connected by two steel plates, see Fig. 3. M8 bolts threaded through the steel plates were used to manually adjust the alignment of the glass beam and the tendons prior to post-tensioning. Four brackets were used for each beam, applied at an interval of $750 \mathrm{~mm}$, starting at $375 \mathrm{~mm}$ from the beam end.

3. Aluminium blocks (alloy EN AW-6005-T5) were placed at the beam ends to introduce and spread the post-tensioning force over the glass beam end surface.

4. At the far ends, the tendons were bolted into steel anchor blocks. These steel blocks contained two threaded holes in longitudinal beam direction, through which two M12 threaded bars were fed.

5. At beam end A, see Figs. 2 and 4, a torque was manually applied on the two threaded bars, which pressed onto the aluminium block. In that way, the 
Fig. 3 Buckling restraint; schematic a side view and $\mathbf{b}$ cross-section; $\mathbf{c}$ in application

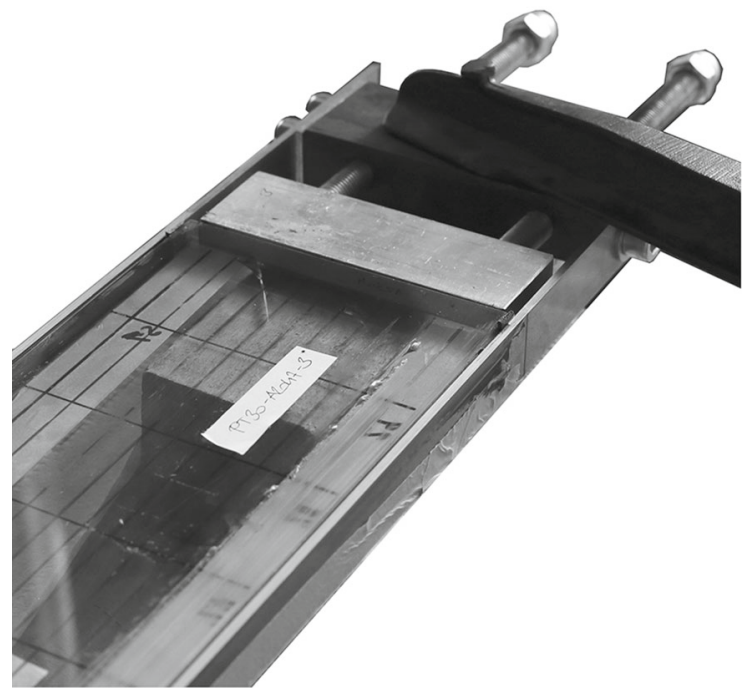

Fig. 4 Post-tensioning setup-side A

tendons were extended, and in turn, a compressive force was exerted on the glass beam via the aluminium blocks. At beam end B, see Figs. 2 and 5, the applied pre-tensioning force was measured by a load cell. The strain in each tendon was measured by strain gauges and steered individually by separately tightening the threaded bars, assuring that equal force was introduced in both tendons. Axial compression in the glass was monitored by strain gauges applied at the mid-span on front and back glass surface. The position of strain gauges on the steel tendons (ST1, ST2) and glass beam (GL1, GL2) is shown in Fig. 6. The strain gauges on the

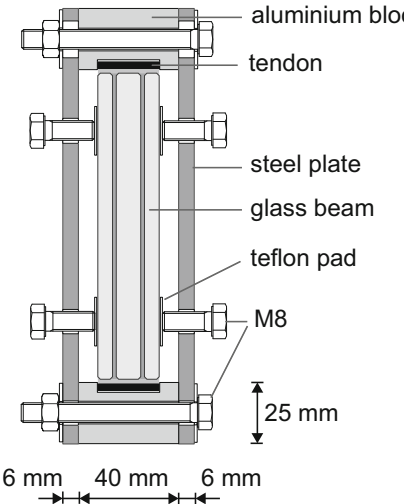

(b)

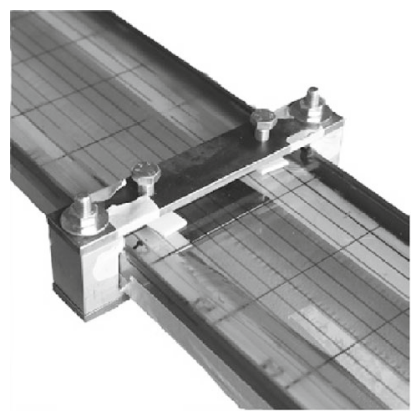

(c)

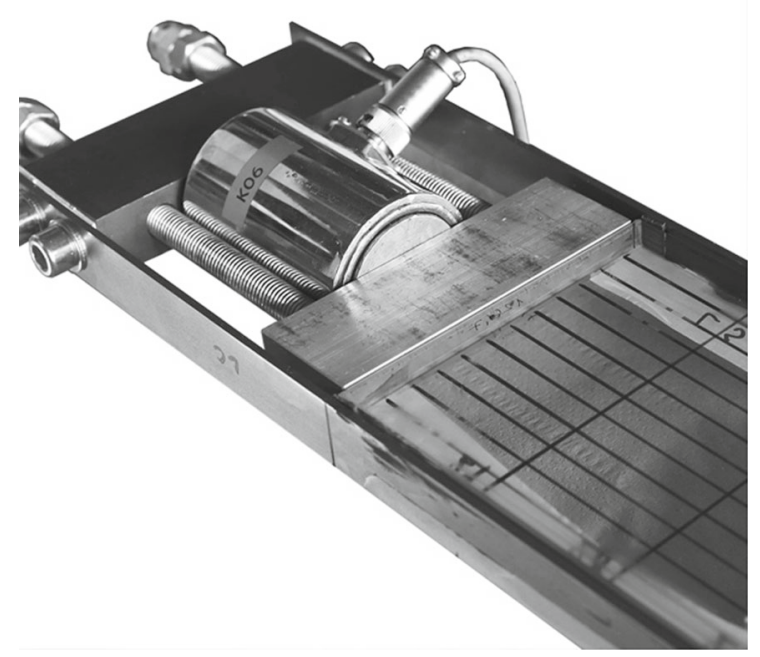

Fig. 5 Post-tensioning setup—side B

tendons were applied with a $100 \mathrm{~mm}$ offset from the glass beam central axis (lengthwise) in order to avoid contact with the central support in the bending setup described in Sect. 3.2.

6. After reaching the desired post-tensioning force of $30 \mathrm{kN}$, which equals $10.91 \mathrm{MPa}$ of compressive stress in the glass for nominal glass dimensions given in Fig. 1, the $1.5 \mathrm{~mm}$ gap between the glass and the tendons was filled with Araldite ${ }^{\circledR}$ methacrylate adhesive A2047-1. The assembly was then left for the adhesive to cure for $>48 \mathrm{~h}$.

7. After the curing of the adhesive, the load cell was removed by tightening the threaded bars at beam 


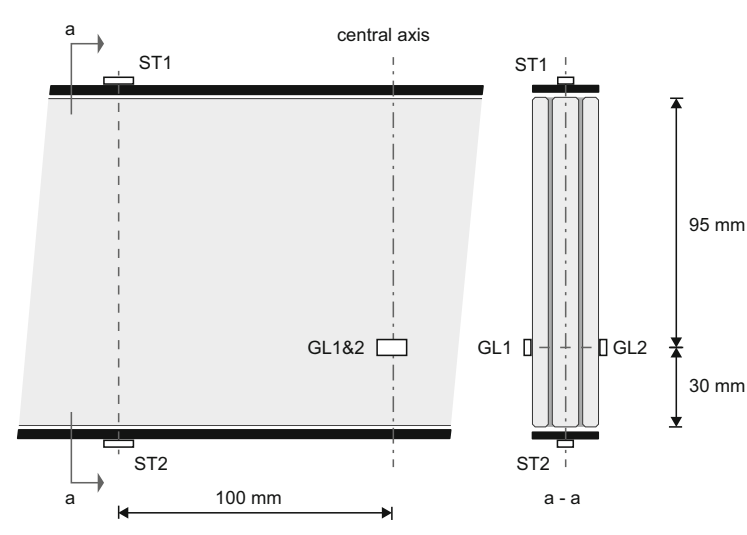

Fig. 6 Position of strain gauges on steel (ST1, ST2) and glass (GL1, GL2)

end $\mathrm{B}$, thereby releasing the force from the load cell and diverting it through the threaded bars into the aluminium block.

8. Finally, the buckling restraints were removed after curing, allowing the adhesive to laterally stabilise the glass beam against the tendons.

\subsection{Bending setup}

The post-tensioned glass beams were tested in a statically indeterminate five-point bending test setup. The test setup was devised at Ghent University, Laboratory for Research on Structural Models, and is described in detail in Martens et al. (2016). A schematic representation is provided in Fig. 7. The setup consisted of three vertical supports spaced at a distance of 1450 $\mathrm{mm}$ with a loading point in the centre of each span. The central support was designed to allow certain flexibility in the test setup (Martens et al. 2016) resulting in lower support stiffness (spring support) in reference to the outer vertical supports. The beams were laterally supported at the outer vertical supports and within the spans at $950 \mathrm{~mm}$ from the end supports. Steel blocks were placed between the beam specimens and cylindrically shaped load points/mid-support in order to distribute the load/reaction over a larger surface.

The load was applied by a $100 \mathrm{kN}$ servo-hydraulic actuator with a stroke of $250 \mathrm{~mm}$, hinge-connected to a loading beam which distributed the force equally over the two loading points. Two load cells were used in the setup: one integrated in the loading mechanism measuring the total applied force (the sum of the two loading points), and the second at the mid-support measuring the reaction force. Five linear variable differential transformers (LVDTs) measured the vertical displacement of the three supports, and the vertical deflection of the beam at the load-points. The tests were performed in displacement control at a rate of $0.1 \mathrm{~mm} / \mathrm{s}$.

The whole setup was placed inside an actively controlled climatic chamber thereby guaranteeing a relative humidity of $55 \%$ and a test temperature of either 23 or $60^{\circ} \mathrm{C}$. Prior to the tests, the beams were conditioned for $24 \mathrm{~h}$ in the climatic chamber to ensure an even test temperature throughout the specimens (Louter et al. 2012). Three specimens were tested in each temperature series.

\section{Results and discussion}

\subsection{Post-tensioning}

Exemplary plots of the data obtained during the posttensioning procedure are provided in Fig. 8 in which the strains measured on the two steel tendons and the front and back glass surface are plotted in function of the total applied axial pre-load measured by the load cell at the beam end. The curves show discrete steps due to manually applied torque on the threaded bars by which the pre-load was introduced. At the pre-load level of

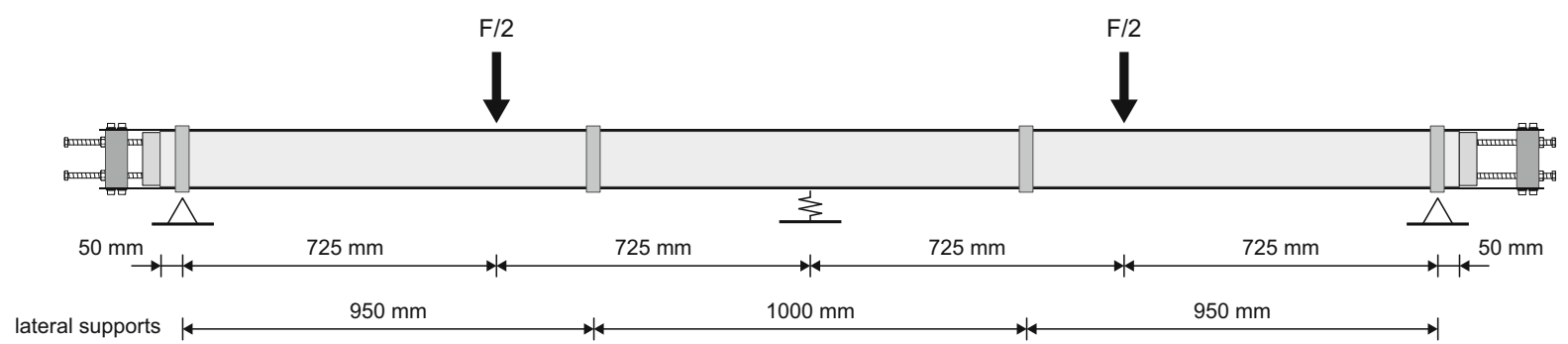

Fig. 7 Five-point bending test setup 

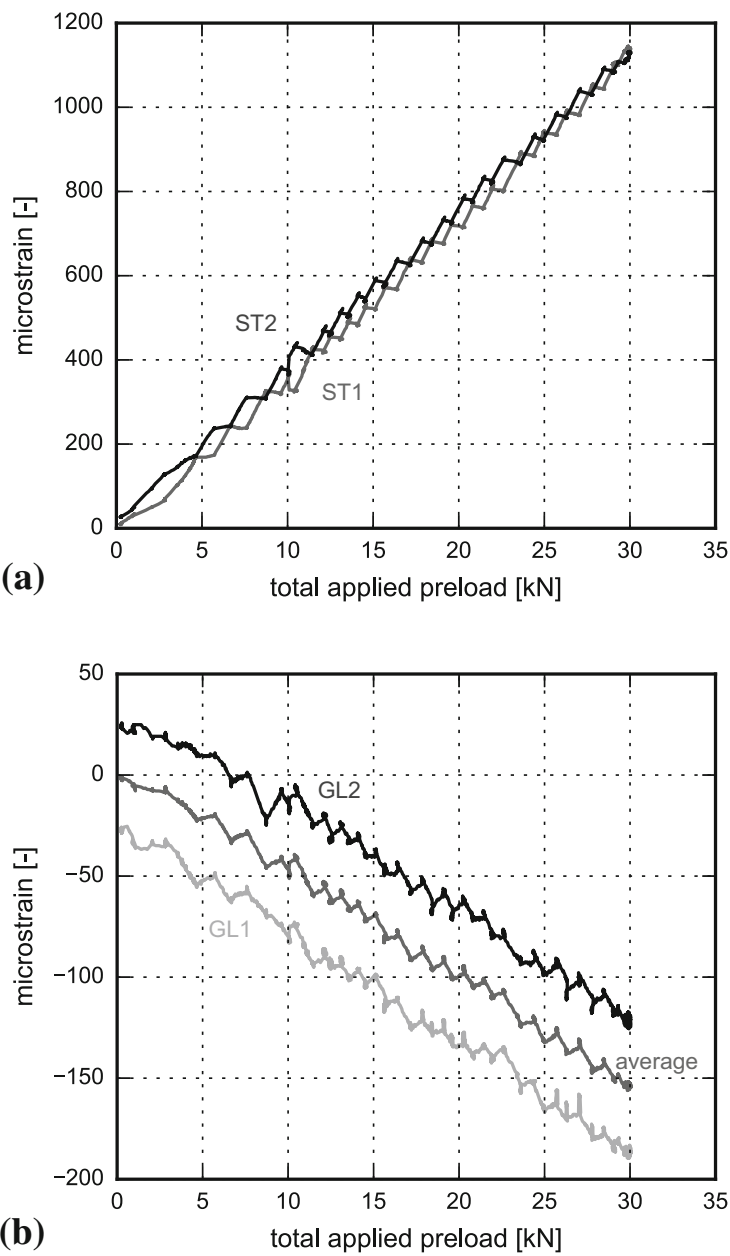

Fig. 8 Strain in the steel tendons (a) and glass (b) in function of the total applied preload

$30 \mathrm{kN}$, the average strain in the glass, i.e. the average of the measured strain at the back and front surface of the glass, reaches a microstrain of -153 which corresponds to a compressive pre-stress of $-10.71 \mathrm{MPa}$; this value is in close agreement with the pre-stress calculated for the nominal glass dimensions which equals $-10.91 \mathrm{MPa}$. It should be noted that the strain recordings, as plotted in Fig. 8b, start with a certain offset from zero. This is due to the fact that the signal of the strain gauges was zeroed when the beams were in an upright position, in which the beam laminates show an inherent initial imperfection or "global bow" about the weak axis. The global bow was estimated by means of a linear string and a calliper, resulting in values of 0.5 to $3 \mathrm{~mm}$, which is in line with the findings of Belis et al. (2010). Once the beams were placed horizontally on the table and aligned with the tendons by means of buckling restraints, they were forced to straighten along with the tendons, thereby compensating the initial global bow. This manipulation and bending about the weak axis resulted in a bending stress at the outer glass surfaces in the order of 1 to $4 \mathrm{MPa}$ in either tension or compression depending on the surface considered, which can be retrieved from the measured strain at zero pre-load as plotted in Fig. 8b. When increasing the pre-load, the strains at both outer glass surfaces develop similarly as can be seen from the parallel curves in Fig. 8b. This demonstrates that no specific buckling/bending phenomena around the weak axis occurred while pre-stressing the glass beams, i.e. at least not in the middle of the beams where the strain gauges were applied. From this it was concluded that the devised post-tensioning mechanism, with additional buckling restraints, effectively prevented any relative lateral movement of the glass and steel tendons, which is a valuable improvement compared to the system applied in the earlier studies (Louter et al. 2014).

\subsection{Bending test results}

The results of the five-point bending tests are provided in Table 1 and Figs. 9, 10 and 11. Table 1 lists the total pre-load applied by the post-tensioning tendons, initial cracking load, ultimate failure load, post-cracking performance and ultimate failure mode. Post-cracking performance expresses the level of achieved ultimate load capacity as a percentage of the initial cracking load. Furthermore, the location of the first glass crack (right/left span or central support) is indicated with the initial cracking load.

Figure 9 displays the load-displacement curves resulting from the five-point bending tests at 23 and $60^{\circ} \mathrm{C}$. The displacement was taken as the mean value of the recorded displacements at the two loading points. Only two out of three specimens tested at $60^{\circ} \mathrm{C}$ are presented due to an error in the data acquisition system during one of the tests. It can be seen that all the specimens showed linear elastic behaviour in the initial phase until the first crack in the glass occurred. In the beam series tested at $23{ }^{\circ} \mathrm{C}$ (PT-23), the first crack typically appeared in one of the spans, at an average load of $37.72 \mathrm{kN}$, quickly followed by the cracks in the other span and at the central support. At $60^{\circ} \mathrm{C}$ (PT-60) the ini- 
Table 1 Results of five-point bending tests on post-tensioned beams at 23 and $60^{\circ} \mathrm{C}$

\begin{tabular}{|c|c|c|c|c|c|}
\hline Specimen & $\begin{array}{l}\text { Total applied } \\
\text { pre-load [kN] }\end{array}$ & $\begin{array}{l}\text { Initial cracking load } \\
{[\mathrm{kN}] / \text { location* }}\end{array}$ & $\begin{array}{l}\text { Ultimate failure } \\
\text { load }[\mathrm{kN}]\end{array}$ & $\begin{array}{l}\text { Post-cracking } \\
\text { performance [ } \% \text { of } \\
\text { initial cracking load] }\end{array}$ & Ultimate failure mode \\
\hline P-23_1 & 30.03 & $38.11 / \mathrm{R}$ & 85.66 & 225 & Glass in compression \\
\hline P-23-2 & 30.22 & $38.38 / \mathrm{L}$ & 84.88 & 221 & Glass in compression \\
\hline P-23_3 & 30.30 & $36.67 / \mathrm{L}$ & 85.14 & 232 & Steel in tension \\
\hline Average $[k N]$ & 30.18 & 37.72 & 85.23 & 226 & \\
\hline$C V[\%]^{* *}$ & 0.38 & 1.99 & 0.38 & 2.03 & \\
\hline P-60_1 & 30.11 & $33.00 / \mathrm{C}$ & 70.37 & 213 & Glass in compression \\
\hline P-60_2 & 29.90 & $30.05 / \mathrm{C}$ & 70.80 & 232 & Glass in compression \\
\hline P-60_3 & 30.02 & $36.99 / \mathrm{C}$ & 75.08 & 203 & Glass in compression \\
\hline Average $[k N]$ & 30.01 & 33.50 & 72.08 & 216 & \\
\hline$C V[\%]$ & 0.29 & 7.98 & 2.95 & 5.59 & \\
\hline
\end{tabular}

* $L$ left span; $R$ right span; $C$ central support

$* *$ Coefficient of Variation

Fig. 9 Load-displacement diagrams of post-tensioned beams tested at 23 and $60^{\circ} \mathrm{C}$

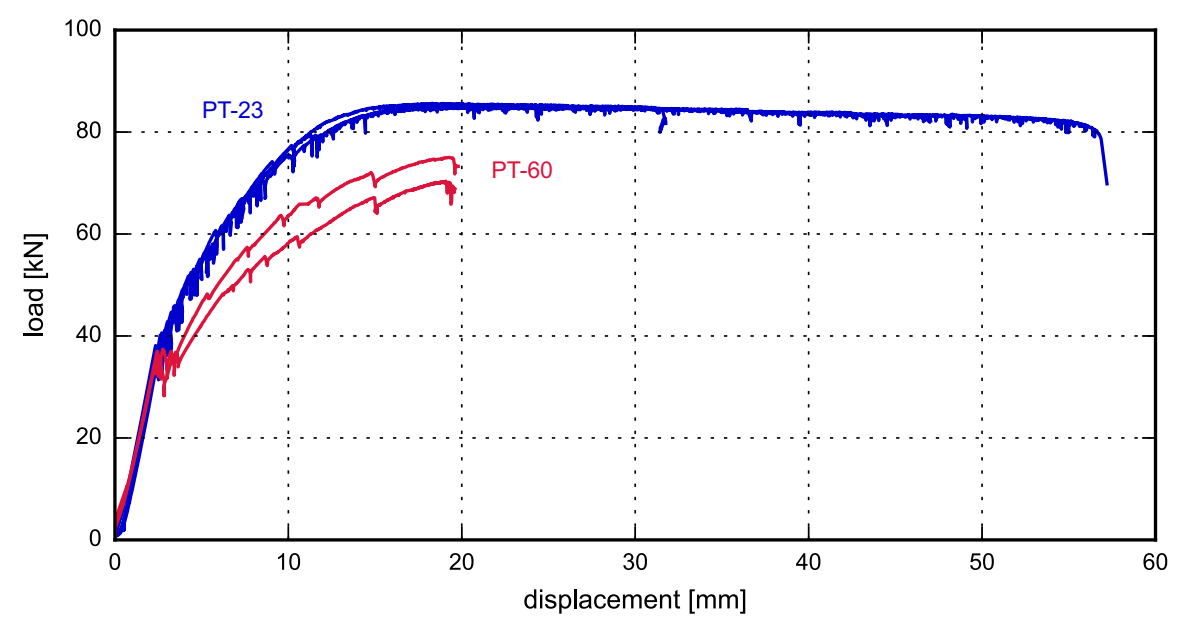

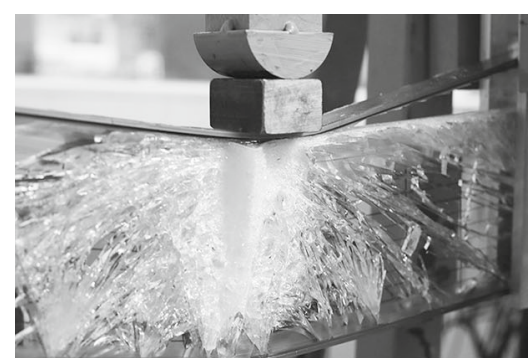

(a)

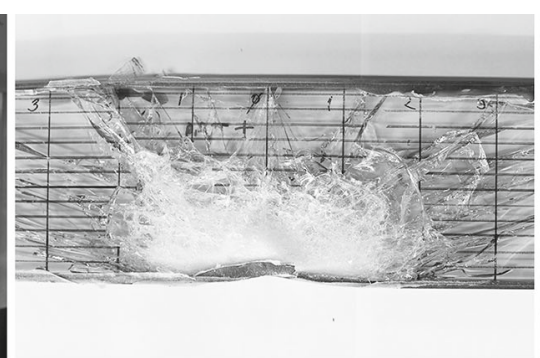

(b)

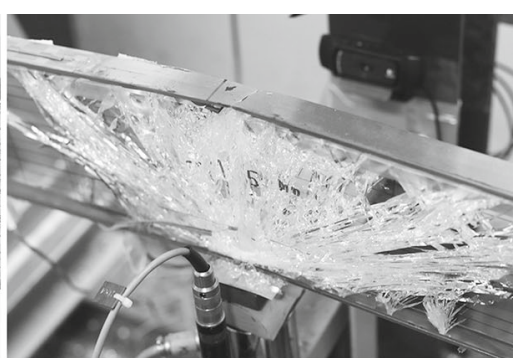

(c)

Fig. 10 Failure modes: glass failure in compression in the span (a) and at mid-support (b); steel failure in tension (c)

tial glass cracking happened first at the central support, reaching an average load of $33.50 \mathrm{kN}$, with successive cracks in the spans. Increase in load caused further cracking of the beams, gradually reducing the beam stiffness, which can be seen in the decreasing slope of the load-displacement curves. After reaching sub- 


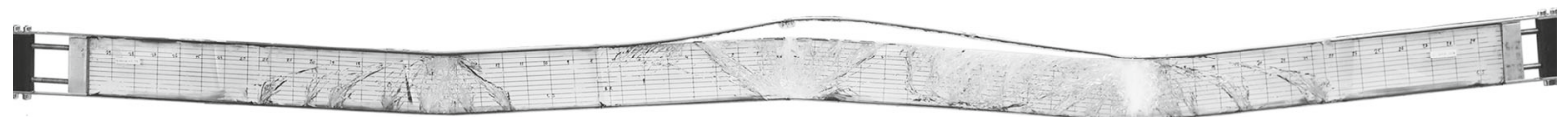

(a)

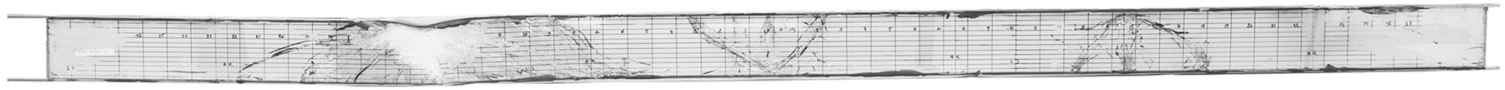

(b)

Fig. 11 Typical crack distribution and deformation of the beams tested at $23^{\circ} \mathrm{C}$ (a) and $60{ }^{\circ} \mathrm{C}(\mathbf{b})$

stantial post-cracking loads, beams at $23^{\circ} \mathrm{C}$ exhibited a long ductile trajectory enabled by the yielding of the tendons, while the beams tested at $60^{\circ} \mathrm{C}$ failed before this yielding phase could be reached. The average maximum load in PT-23 series was $85.23 \mathrm{kN}$, and $72.08 \mathrm{kN}$ in the PT-60 series. Ultimate failure was in most cases caused by an explosive failure of the glass in compression in one of the zones under the maximum bending moment. In only one test at $23^{\circ} \mathrm{C}$ the ultimate strain capacity of the steel tendon was reached resulting in the rupture of the tendon at the mid-support. Ultimate failure modes observed in the tests are presented in Fig. 10, differentiating between compressive glass failure either in the span or at the mid-support and tensile failure of the steel tendon. Due to the high amount of energy stored in the system, the ultimate failure was explosive, but the beams still maintained their integrity through the adhesive bond, avoiding the collapse observed in the systems where only mechanical anchoring was applied (Louter et al. 2014).

Figure 11 gives a comparison between typical specimens tested at 23 and $60^{\circ} \mathrm{C}$, in terms of crack distribution and achieved deformation/ductility of the beam. A somewhat more extensive glass cracking can be observed at $23{ }^{\circ} \mathrm{C}$, as well as significant displacement capacity enabled by the yielding of the steel tendons. Although no failure of the adhesive was observed during the tests, in several specimens the explosive nature of the ultimate failure caused sudden debonding of the tendon from the failed cross-section to the next critical section, as can be seen in Fig. 11a.

\subsection{Temperature effect}

The results of the five-point bending tests at 23 and $60^{\circ} \mathrm{C}$ indicate significant effects of temperature increase on the structural response of post-tensioned beams. The initial cracking load was decreased by $11 \%$ on average at $60^{\circ} \mathrm{C}$. The location of the initial crack shifted from the spans to the central support, indicating a change in the moment distribution. In the postcracking phase, the specimens showed limited ductility with less extensive crack distribution and an absence of plastic yielding phase, and finally a $15 \%$ lower ultimate failure load on average.

The reduction of the initial cracking strength at increased temperature can be explained by two phenomena. Firstly, at increased temperature the shear modulus of the adhesive is lower (Huntsman $2013^{\circledR}$ ) which reduces the composite action between the glass and the steel tendon, resulting in a lower moment of inertia and thus a lower bending moment resistance. A similar effect has also been observed in Louter et al. (2012). Secondly, the differential thermal expansion between the glass beam and the steel tendons results in the loss of applied pre-stress at increased temperature. More specifically, while increasing the temperature, the stainless steel tendon expands more than the glass beam, resulting in a decompression of the glass beam. The coefficient of thermal expansion of stainless steel is $16 \times 10^{-6} / \mathrm{K}(\mathrm{EN} \mathrm{1993-1-4} \mathrm{2006),} \mathrm{but}$ only $9 \times 10^{-6} / \mathrm{K}$ for annealed float glass (EN 57212004 ); for a temperature difference of $37^{\circ} \mathrm{C}$ and a beam length of $3 \mathrm{~m}$, the differential expansion in each tendon amounts to $0.78 \mathrm{~mm}$, which corresponds to a total decompression force of $7.80 \mathrm{kN}$. The resulting tensile stress in the glass amounts to $2.45 \mathrm{MPa}$, thereby reducing the compressive prestress from initially applied -10.91 to $-8.46 \mathrm{MPa}$; assuming a characteristic tensile strength of glass of $45 \mathrm{MPa}$ (EN 572-1 2004), this equals a $4 \%$ decrease of the initial cracking strength of the post-tensioned glass beam. The combination of the two aforementioned effects is likely to have caused the overall reduction of initial cracking strength at $60^{\circ} \mathrm{C}$. 
Table 2 Comparative results of the tests on post-tensioned and reinforced beams at 23 and $60{ }^{\circ} \mathrm{C}$

\begin{tabular}{|c|c|c|c|c|c|c|}
\hline Series & P-23 & P-60 & S-23 & S-60 & $\mathrm{H}-23$ & $\mathrm{H}-60$ \\
\hline \multicolumn{7}{|l|}{ Initial cracking load } \\
\hline Average [kN] & 37.72 & 33.50 & 23.43 & 21.37 & 17.78 & 16.72 \\
\hline $\mathrm{CV}[\%]$ & 1.99 & 7.98 & 2.95 & 4.73 & 10.18 & 21.89 \\
\hline \multicolumn{7}{|l|}{ Ultimate failure load } \\
\hline Average $[\mathrm{kN}]$ & 85.23 & 72.08 & 82.78 & 60.99 & 37.62 & 34.34 \\
\hline $\mathrm{CV}[\%]$ & 0.38 & 2.95 & 0.92 & 4.87 & 0.90 & 3.73 \\
\hline \multicolumn{7}{|l|}{ Post-cracking performance } \\
\hline Average [\% of initial cracking load] & 226 & 216 & 354 & 286 & 212 & 188 \\
\hline $\mathrm{CV}[\%]$ & 2.03 & 5.59 & 3.95 & 5.94 & 5.66 & 19.15 \\
\hline
\end{tabular}

The observed shift of the location of the first crack from the span at $23^{\circ} \mathrm{C}$ to the central support at $60^{\circ} \mathrm{C}$ can also be explained by the reduction of the moment of inertia of the beam caused by the lower shear stiffness of the adhesive at $60^{\circ} \mathrm{C}$. The moment distribution of an indeterminate system depends on the relative stiffness of the supports and the beam stiffness. The maximum moment in a statically indeterminate system spanning over three fully rigid supports is the hogging moment at the central support; given the specific design of the test setup with a lower central support stiffness, the moment distribution was shifted towards the spans, i.e. the moment on the central support was reduced which in turn increased the span moments causing the first crack at $23{ }^{\circ} \mathrm{C}$ to appear in either right or left span. In contrast, a reduction of beam stiffness, assuming the same relative support stiffness, changes the conditions closer to a system over three fully rigid supports with the maximum moment being on the central support, which explains the location of the initial glass cracking in the beam tests at $60^{\circ} \mathrm{C}$. However, it should be noted that the known scatter in glass strength can also influence the location of the first crack.

The reduced ductility in post-cracking response at $60{ }^{\circ} \mathrm{C}$ may be attributed to the viscoelastic properties of the SentryGlas ${ }^{\circledR}$ interlayer. More specifically, the shear modulus decreases with a rise in temperature, particularly at the test temperature above its glass transition temperature of $55^{\circ} \mathrm{C}$ (Santarsiero et al. 2016). In a fully cracked section, the local lateral stability of glass in compression was more difficult to maintain at high temperature, leading to explosive failure and local buckling of the interlayer at lower ultimate loads. Due to this premature failure of glass in compression, the yielding of the tendons could not be reached.

\subsection{Comparison of post-tensioned and reinforced beams}

Table 2 gives a summary of the five-point bending tests at 23 and $60^{\circ} \mathrm{C}$ on post-tensioned beams explored in the present study (PT-23, PT-60) and the reinforced beams with solid (S-23, S-60) and hollow (H-23, S-60) reinforcement presented in Martens et al. (2016), in terms of the average initial cracking load, ultimate failure load, and post-cracking performance, i.e. the ultimate failure as the percentage of the initial cracking load. Note that the cross-sectional area of the steel reinforcement differs between the test series (PT, S, H). Figure 12 shows an overview of the typical load-displacement curves of the tested beam series. Post-tensioned beams reached significantly higher initial cracking load, at both test temperatures. The increase amounts to $61 \%$ at $23^{\circ} \mathrm{C}$ and $57 \%$ at $60^{\circ} \mathrm{C}$ compared to the reinforced beams with a solid reinforcement, despite the higher reinforcement area, and to 112 and $100 \%$ in reference to the beams with a hollow section reinforcement with the lowest reinforcement area at 23 and $60^{\circ} \mathrm{C}$, respectively. This can partly be attributed to the higher moment of inertia of the post-tensioned beams. However, with similar cross-sectional properties as shown in Fig. 1, assuming perfect shear transfer in the bonds, the moment of inertia of the post-tensioned beams is only $13 \%$ higher than the moment of inertia of the solid section reinforced beams, and $51 \%$ higher than that of the hollow section reinforced beams. The increase 
Fig. 12 Load displacement diagrams of post-tensioned and reinforced beams tested at 23 and $60^{\circ} \mathrm{C}$

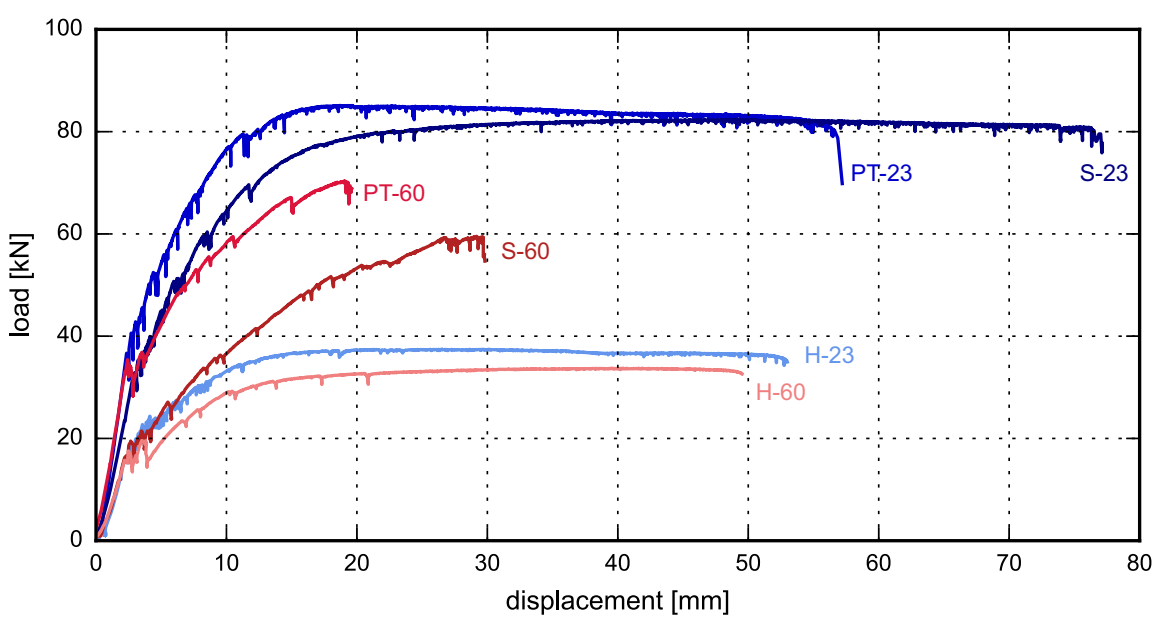

in initial cracking load can therefore not fully result from the increase in the moment of inertia and is likely to predominantly result from the applied compressive prestress. This demonstrates the effectiveness of posttensioning in enhancing the apparent strength of the glass beams. Furthermore, the adhesive shielding the glass edge may have a positive effect on the glass strength resulting from the suppression of sub-critical crack growth induced by humidity (Wiederhorn 1967). In addition, other phenomena such as crack-face bridging by the adhesive and crack closure stresses generated within the flaw by a thermal expansion difference between the glass and the adhesive could play a role (Overend and Louter 2015). However, the latter effects require a more in depth investigation.

In the post-cracking phase, the beams showed comparable structural response, particularly the two series, PT and S, with a similar moment of inertia and crosssectional area of steel reinforcement. The stiffness of the beams continuously decreased with extensive cracking, until reaching the yielding phase at $23^{\circ} \mathrm{C}$, while at $60^{\circ} \mathrm{C}$ the compressive glass failure preceded this phase resulting in lower failure loads and reduced ductility. All the beam series showed substantial postcracking performance, reaching at least twice the initial cracking load prior to ultimate failure. Reinforced beams showed a more extensive post-cracking ductile trajectory, due to the applied compressive pre-stress in the PT beams which caused earlier and more explosive failure of the compressive glass zone, as previously observed in Louter (2013). Reinforced beams with the hollow profile, series $\mathrm{H}$, entered the yielding phase at much lower load levels, and failed due to the rupture of the reinforcement both at 23 and $60^{\circ} \mathrm{C}$.

\section{Conclusions}

Present study has investigated a hybrid system of posttensioned glass beams, in which the prestress was applied through mechanically anchored and subsequently adhesively bonded flat stainless steel tendons placed along the longitudinal glass edges. The structural behaviour of the beams was explored in a statically indeterminate system through five-point bending tests performed at 23 and $60^{\circ} \mathrm{C}$. The following is concluded:

- Lateral stability of a hybrid system of post-tensioned glass beams is ensured by connecting the compressed glass element, which is prone to buckling, with the tensile steel elements along the beam length.

In the post-tensioning process, it was shown that the buckling stability of the compressed beams can be achieved through the application of lateral restraint brackets. By aligning the glass with the tendons prior to post-tensioning, global bow of the glass beams was compensated, and the 'straightness' of the specimens was maintained with increasing pre-load, ensuring lateral stability with no further bending about the weak axis. In service state, after curing of the adhesive, it was shown that the restraints can be removed, and that the adhesive bond efficiently stabilises the beams.

- Post-tensioned beams reach high initial cracking loads in five-point bending tests at $23^{\circ} \mathrm{C}$, followed by a ductile post-cracking behaviour which provides safety and redundancy to the system.

The beams showed linear elastic response prior to the first glass crack, followed by extensive cracking which 
gradually reduced the stiffness of the beams, leading to the ultimate failure. At $23^{\circ} \mathrm{C}$ a long ductile trajectory enabled by the yielding of the steel tendons preceded the ultimate failure, which was caused by the compressive failure of glass or rupture of steel in tension.

- Temperature increase has a significant effect on the structural response of post-tensioned beams in lowering the initial cracking strength and ultimate failure loads and limiting post-cracking ductility.

Temperature increase to $60^{\circ} \mathrm{C}$ lowered the initial cracking load due to the reduced moment of inertia, caused by reduced adhesive shear stiffness, and decompression of the beams, caused by differential thermal expansion of the steel and the glass. In the post-cracking phase, the beams showed only limited ductility and failed due to compressive glass failure before the yielding stress in the tendons could be reached. Achieved ultimate failure loads were still significantly high, reaching more than twice the initial cracking load before failure.

- The application of compressive pre-stress effectively increases the initial cracking load of posttensioned glass beams.

The efficiency of the system has been derived from the comparison with reinforced glass beams produced in the same batch with consistent overall dimensions, which were tested on the same bending setup. The results have shown that the apparent tensile strength of glass can be effectively enhanced by activating the reinforcement tendons for the application of compressive prestress in glass.

Acknowledgements The Swiss National Science Foundation is gratefully acknowledged for funding the present research through SNF Grants 200021_143267 and 200020_159914. The travelling for the writing of this paper has been supported by the Ph.D. Mobility Grant, awarded by the doctoral program in Civil and Environmental Engineering (ENAC), École Polytechnique Fédérale de Lausanne (EPFL). Also the Agency for Innovation by Science and Technology in Flanders (IWT) is gratefully acknowledged for supporting this work (Grant no. 141526). Furthermore, Kuraray Co. Ltd. (SentryGlas ${ }^{\circledR}$ ) and Lerobel N.V. (glass processing) are acknowledged for supporting the production of the test specimens. Finally, M.Sc. student An Bogaert and the technicians Dennis Elias and Eric Vonck are acknowledged for providing invaluable assistance in the experimental work.

\section{Compliance with ethical standards}

Conflict of interest The authors declare that they have no conflict of interest.
Open Access This article is distributed under the terms of the Creative Commons Attribution 4.0 International License (http://creativecommons.org/licenses/by/4.0/), which permits unrestricted use, distribution, and reproduction in any medium, provided you give appropriate credit to the original author(s) and the source, provide a link to the Creative Commons license, and indicate if changes were made.

\section{References}

Belis, J., Depauw, J., Callewaert, D., Delincé, D., van Impe, R.: Failure mechanisms and residual capacity of annealed glass/SGP laminated beams at room temperature. Eng. Fail. Anal. 16, 1866-1875 (2009). doi:10.1016/j.engfailanal. 2008.09.023

Belis, J., Mocibob, D., Luible, A., Vandebroek, M.: On the size and shape of initial out-of-plane curvatures in structural glass components. Constr. Build. Mater. 25, 2700-2712 (2010). doi:10.1016/j.conbuildmat.2010.12.021

Bos, F., Veer, F., Hobbelman, G., Louter, C.: Stainless steel reinforced and post-tensioned glass beams. In: ICEM1212th International Conference on Experimental Mechanics (2004)

Cupać, J., Louter, C.: Post-tensioned structural glass beamscomparative experimental study. In: Advanced Building Skins, pp. 165-172 (2015)

EN 1993-1-4: Eurocode 3-design of steel structures-part 14: general rules-supplementary rules for stainless steels (2006)

EN 572-1: Glass in building-basic soda lime silicate glass products-part 1: definitions and general physical and mechanical properties (2004)

Engelmann, M., Weller, B.: Post-tensioned glass beams for a 9 m spannglass bridge. Struct. Eng. Int. 26, 103-113 (2016). doi:10.2749/101686616X14555428759000

Huntsman ®: Technical data sheet, Araldite ${ }^{\circledR} 2047-1$, structural adhesives (2013)

Jordão, S., Pinho, M., Martins, J.P., Santiago, A., Neves, L.C.: Behaviour of laminated glass beams reinforced with prestressed cables. Steel Constr. 7, 204-207 (2014). doi:10. 1002/stco.201410027

Louter, C.: Reinforced and post-tensioned glass beams. In: Glass Performance Days, pp. 353-355. Tampere (2013)

Louter, C., Belis, J., Veer, F., Lebet, J.-P.: Durability of SGlaminated reinforced glass beams: effects of temperature, thermal cycling, humidity and load-duration. Constr. Build. Mater. 27, 280-292 (2012). doi:10.1016/j.conbuildmat. 2011.07.046

Louter, C., Cupać, J., Lebet, J.-P.: Exploratory experimental investigation on post-tensioned structural glass beams. J. Facade Des. Eng. 2, 3-18 (2014). doi:10.3233/FDE- 130012

Martens, K., Caspeele, R., Belis, J.: Development of reinforced and post-tensioned glass beams-review. J. Struct. Eng. 142, 1-23 (2015). doi:10.1061/(ASCE)ST.1943-541X. 0001453

Martens, K., Caspeele, R., Belis, J.: Experimental investigations of statically indeterminate reinforced glass beams. Constr. Build. Mater. 119, 296-307 (2016). doi:10.1016/ j.conbuildmat.2016.04.151 
Nhamoinesu, S., Overend, M.: The mechanical performance of adhesives for a steel-glass composite Façade system. In: Challenging Glass, vol. 3 (2012)

Overend, M., Louter, C.: The effectiveness of resin-based repairs on the inert strength recovery of glass. Constr. Build. Mater. 85, 165-174 (2015). doi:10.1016/j.conbuildmat.2015.03. 072

Santarsiero, M., Louter, C., Nussbaumer, A.: The mechanical behaviour of SentryGlas ionomer and TSSA silicon bulk materials at different temperatures and strain rates under uniaxial tensile stress state. Glass Struct. Eng. 2, 395-415 (2016). doi:10.1007/s40940-016-0018-1
Schober, H., Gerber, H., Schneider, J.: Ein Glashaus für die Therme in Badenweiler. Stahlbau 73, 886-892 (2004). doi:10.1002/stab.200490213

Stelzer, I.: High performance laminated glass. In: Challenging Glass 2, Delft (2010)

Valarinho, L., Correia, J.R., Branco, F.A.: Experimental study on the flexural behaviour of multi-span transparent glassGFRP composite beams. Constr. Build. Mater. 49, 10411053 (2013). doi:10.1016/j.conbuildmat.2012.11.024

Wiederhorn, S.M.: Influence of water vapor on crack propagation in soda-lime glass. J. Am. Ceram. Soc. 50, 407-414 (1967). doi:10.1111/j.1151-2916.1967.tb15145.x 